\title{
KEMITRAAN DALAM PELAYANAN PUBLIK : SEBUAH PENJELAJAHAN TEORITIK
}

Fatmawati

Fakultas Ilmu Sosial dan Ilmu Politik Universitas Muhammadiyah Makassar Jl. Sultan Alauddin No. 259 Makassar 90221 Telp. 0411 - 866972 ext. 107 Fax. 0411 - 865588

\begin{abstract}
Public services in recent years become a central issue has forced all parties, both state and public institutions to perform again in its implementation regulations. Although the provision of public services is an obligation that must be done by the government as the organizer of the state. However, the obligation to provide such services are still not able to give satisfaction to the user community. To realize good governance requires the synergistic partnership between agencies both within and outside the government bureaucracy. The agencies include the private sector and civil society. Partnerships must be built in an environment that is transparent, which is built with good communication, especially in any decision-making. This meant that the policies are formulated to meet the expectations of society. Thus, the partnership between government, communities and businesses are expected to promote the establishment of governance, development and public services more democratic and more professional.
\end{abstract}

Keywords: Bureaucratic Management, Professional, Public Service.

\section{ABSTRAK}

Pelayanan publik dalam beberapa tahun terakhir menjadi isu sentral telah memaksa semua pihak, baik negara dan lembaga publik untuk tampil lagi dalam peraturan pelaksanaannya. Meskipun pelayanan publik adalah kewajiban yang harus dilakukan oleh pemerintah sebagai penyelenggara negara. Namun, kewajiban untuk menyediakan layanan tersebut masih belum mampu memberikan kepuasan kepada masyarakat pengguna. Untuk mewujudkan tata pemerintahan yang baik membutuhkan kemitraan sinergis antara lembaga baik di dalam dan di luar birokrasi pemerintah. Badan-badan termasuk sektor swasta dan masyarakat sipil. Kemitraan harus dibangun dalam lingkungan yang transparan, yang dibangun dengan komunikasi yang baik, terutama dalam pengambilan keputusan. Ini berarti bahwa kebijakan yang diformulasikan untuk memenuhi harapan masyarakat. Dengan demikian, kemitraan antara pemerintah, masyarakat dan bisnis diharapkan untuk mendorong terwujudnya pelayanan pemerintahan, pembangunan dan publik yang lebih demokratis dan lebih profesional.

Kata kunci: Manajemen Birokrasi, Profesional, Pelayanan Publik. 


\section{A. PENDAHULUAN}

Tulisan ini dimaksudkan sebagai sumbangan pikiran dalam rangka upaya peningkatan pelayanan publik oleh pemerintah. Salah satu tugas pokok pemerintah yang terpenting adalah memberikan pelayanan umum kepada masyarakat, oleh karena itu organisasi pemerintah sering pula disebut sebagai "pelayanan masyarakat" (public service) (Wasistiono, 2009). Walaupun tugas dan fungsi pelayanaan publik merupakan kewenangan dan tanggung jawab pemerintah namun dengan prinsip partisipasi mayarakat sebagai salah satu pilar kepemerintahan yang baik atau good governance, masyarakat sebenarnya perlu dilibatkan lebih jauh dalam kegiatan penyediaan pelayanan, mulai dari tahap perencanaan, pelaksanaan, dan pengawasan. Dengan demikian paradigma dominan yang selama ini cenderung memandang pelayanan publik menjadi kewajiban dan tanggung jawab pemerintah, sementara masyarakat berada di pihak yang pasif, yang hanya menunggu dan menagih untuk mendapatkan pelayanan tampaknya perlu dikaji ulang. Adanya sinergi antara pemerintah, dunia usaha dan masyarakat memungkinkan kualitas pelayanan menjadi lebih meningkat, karena masyarakat sendiri turut mengawasi pelaksanaannya.

Di negara yang sedang berkembang seperti di Indonesia, kesejahteraan masyarakat sangat tergantung pada kemampuan mereka dalam mengakses dan menggunakan pelayanan publik, akan tetapi permintaan akan pelayanan tersebut umumnya jauh melebihi kemampuan pemerintah untuk dapat memenuhinya. Sebaliknya, pemusatan segala urusan publik hanya kepada negara, pada kenyataannya hanya sebuah retorika, sebab urusan pelayanan publik yang demikian kompleks, mustahil dapat dikerjakan semua hanya oleh pemerintah.

Tuntutan masyarakat untuk mendapatkan pelayanan publik yang berkualitas, berprosedur jelas, dilaksanakan dengan segera dan dengan biaya yang pantas, telah terus mengedepan dari waktu ke waktu. Tuntutan ini berkembang seiring dengan berkembangnya kesadaran bahwa warga negara dalam kehidupan bernegara bangsa yang demokratik memiliki hak untuk dilayani. Adalah kewajiban pejabat-pejabat pemerintahan untuk memberikan pelayanan sesuai dengan tuntutan para warga itu. Namun, apa lacur.? Perubahan-perubahan yang terjadi sepanjang era reformasi ini ternyata belum sepenuhnya mengubah tatanan kehidupan masyarakat di bidang pelayanan publik. Harapan masih sangat jauh bahwa warga masyarakat bisa memperoleh akses yang lapang ke arah pelayanan yang baik dan berkualitas. (Larasati, 2008:255).

Menurut Miftah Thoha (dalam Sedarmayanti, 2009:243), pelayanan publik dapat dipahami sebagai suatu usaha oleh seorang/ kelompok orang, atau institusi tertentu untuk memberikan kemudahan dan bantuan kepada masyarakat dalam rangka mencapai tujuan tertentu. Hanya saja, dalam rangka melakukan optimalisasi pelayanan publik yang dilakukan oleh birokrasi pemerintahan bukanlah tugas yang mudah mengingat usaha tersebut menyangkut berbagai aspek yang telah membudaya dalam lingkaran birokrasi pemerintahan. Oleh karena itu kemudian peran swasta dan masyarakat sangat diharapkan untuk melengkapi pemerintah dalam menciptakan kualitas pelayanan publik yang optimal.

Keterlibatan dunia usaha (swasta) dan masyarakat dalam optimalisasi pelayanan publik tentu saja sangat mendukung dalam pencapaian tujuan besar yaitu Good Governance, dalam konsep Good Governance, peran masyarakat dan sektor swasta menjadi sangat penting karena adanya perubahan paradigma pembangunan dengan meninjau ulang peran pemerintah dalam pembangunan, yang semula berperan sebagai regulator dan pelaku pasar, menjadi bagaimana menciptakan iklim yang kondusif dan melakukan investasi prasarana yang mendukung dunia usaha. Tentu saja hal ini bisa diwujudkan apabila masyarakat dan sektor swasta sendiri sudah memiliki kapabilitas yang memadai.

\section{B. PERGESERAN PARADIGMA PELAYANAN PUBLIK}

Paradigma baru administrasi publik, 
menyebabkan pola hubungan antara negara dengan masyarakat, yang lebih menekankan kepada kepentingan masyarakat. Akibatnya negara dituntut untuk memberikan pelayanan kepada masyarakat dengan lebih baik dan lebih demokratis. Pemahaman yang senada diberikan oleh Denhardt bahwa paradigma baru pelayanan publik (new public services paradigm) lebih diarahkan pada "democracy, pride and citizen". Lebih lanjut dikatakan bahwa "Public servants do not delever customer service, they delever democracy" Oleh sebab itu nilai-nilai demokrasi, kewarganegaraan dan pelayanan untuk kepentingan publik sebagai norma mendasar dalam penyelenggaraan administrasi publik (Larasati, 2008:260)

Pelayanan publik adalah identik dengan representasi dari eksistensi birokrasi pemerintahan, karena berkenaan langsung dengan salah satu fungsi pemerintah yaitu memberikan pelayanan. Oleh karenanya sebuah kualitas pelayanan publik merupakan cerminan dari sebuah kualitas birokrasi pemerintah. Di masa lalu, paradigma pelayanan publik lebih memberi peran yang sangat besar kepada pemerintah sebagai sole provider. Peran pihak di luar pemerintah tidak pernah mendapat tempat atau termarjinalkan. Masyarakat dan dunia swasta hanya memiliki sedikit peran dalam penyelenggaraan pelayanan publik. Oleh karenanya berkenaan dengan reformasi di sektor publik, salah satu prinsip penting yang merubah paradigma pelayanan publik adalah prinsip streering rather than rowing. Berkenaan dengan prinsip ini, pemerintah diharapkan untuk lebih berperan sebagai pengarah daripada sekedar pengayuh. Fungsi pengayuh bisa dilakukan secara lebih efisien oleh pihak lain yang profesional. Prinsip ini menjelaskan bahwa pemerintah tidak dapat secara terus menerus bekerja sendirian, dan harus mulai mengubah paradigma pelayanan agar tujuan dari penyelenggaraan pelayanan dapat tercapai lebih baik lagi.

Perjalanan demokratisasi yang berlangsung di Indonesia memberikan pelajaran yang berharga bagi pemerintah (birokrasi) dan warga negara (citizen). Wajah dan sosok birokrasi kini mengalami perubahan dari birokrasi yang kaku berorientasi ke atas menuju ke arah birokrasi yang lebih demokratis, responsif, transparan, dan partisipatif.

Secara teoritis, Eisler dan Montuori (2001:11) membuat pernyataan yang menarik yang berbunyi "Beginning to recognize and acknowledge Partnership in ourselves and in others, and finding creative alternatives for Dominator thinking and behaviors is a first step towards building a Partnership organization." (memulai dengan mengakui dan memahami kemitraan pada diri sendiri dan orang lain, dan menemukan alternatif yang kreatif bagi pemikiran dan perilaku dominator merupakan langkah pertama ke arah membangun sebuah organisasi kemitraan).

Istilah kemitraan seringkali dipertukarkan dengan banyak istilah lain seperti kolaborasi, aliansi, ko-produksi atau konsorsium. Istilahistilah ini sebenarnya sebagai perwujudan dari kerjasama antar individu atau kelompok yang saling membantu, saling menguntungkan dan secara bersama-sama meringankan pencapaian tujuan yang telah mereka sepakati bersama. Permasalahan definisi ini kemudian diikuti dengan pernyataan mendasar bahwa kemitraan sebagai proses, produk, hasil penjelajahan, atau hasil akhir (BorriniFeyerabend, 1996).

Secara khusus pada bidang pelayanan publik, pengertian kemitraan mengacu kepada dukungan sukarela dan resiprokal (timbal balik) antara dua atau lebih badan sektor publik yang berbeda. Dengan kata lain antar administrasi publik dengan privat, termasuk organisasi nonprofit. Berbagai sektor tersebut saling memberikan dukungan satu sama lain dalam rangka pelayanan publik yang menjadi bagian dari misi pemerintah.

Pengertian kemitraan sebagai kerja bersama (working together) dikemukakan oleh Hodget \& Johson (2001:323) bahwa kemitraan diarahkan untuk mencapai tujuan sebagaimana yang diinginkan individu, kelompok, lembaga atau organisasi untuk menghasilkan suatu keluaran yang bermakna dan berkelanjutan. Dalam kemitraan terjadi relasi antarorganisasi dan dengan relasi tersebut akan tercipta kerja sama. Sistem kemitraan bertumpu pada kepercayaan. dengan ciri-ciri-nya, antara lain: (I) persamaan 
dan organisasi yang lebih landai: (2) hierarki aktualisasi yang luwes (di mana kekuasaan dipedomani oleh nilai-nilai seperti caring dan caretaking); (3) spiritualitas yang berbasis alamiah; (4) tingkat kekacauan yang rendah yang terbentuk dalam sistem; dan (5) persamaan dan keadilan gender.

Masa sekarang model komando dan kontrol ini selain tidak sesuai lagi, juga makin menjadi tidak berlaku. Kekakuan birokrasi bersifat mematikan organisasi yang berkehendak mengarahkan secara efektif di lingkungan yang cepat berubah di mana inovasi dan fleksibilitas merupakan faktor-faktor kunci. Di dalam sistem kemitraan, kreativitas sangat bernilai dan dihargai. Kreativitas kemitraan tidak mengecualikan perubahanperubahan kreatif yang dramatis, sistem tersebut juga mendorong hubungan-hubungan kreatif dan pendekatan-pendekatan kreatif terhadap masalah-masalah sehari-hari. Kreativitas sehari-hari dalam organisasi dapat mendorong perbaikan terus menerus dan perbaikan kualitas, seperti praktik manajerial baru, penghargaan baru, proses pendidikan baru, bagan organisasi baru dan sebagainya.

Jika organisasi dirancang dengan pemikiran sistemik, perbaikan hidup dan prinsipprinsip kemitraan, maka diperlukan pergeseran mendasar dalam cara orang berpikir dan merancang organisasi. Disamping itu organisasi memerlukan jenis kreativitas yang perlu dijaga dan didorong oleh model kemitraan: perlindungan yang luas dan belum begitu dimanfaatkan dari kreativitas sosial dan kewirausahaan sosial.

Kemitraan berusaha melibatkan masyarakat, baik dalam bentuk kelompok maupun individual. Vigoda (2002:527) menyebut mereka sebagai "social players" yang memiliki tingkatan kepentingan, keahlian, sumberdaya dan kemampuan pengambilan keputusan yang bervariasi. Vigoda menyoroti kondisi ideal dari proses kemitraan di mana masyarakat sebagai warga negara dan pemerintah sebagai penanggung jawab pemerintahan bertindak sebagai sepasang "partner" dalam proses pengambilan keputusan. Khususnya dalam proses pemberian pelayanan, warga negara harus diperlakukan sebagai rekan kerja, dan bukan sebagai subjek atau pelanggan.

Kemitraan dalam perspektif hubungan antarorganisasi masa kini dikemukakan oleh Limerick dan Cunnington (1993:6). Menurut keduanya, ada delapan sebagai respon terhadap dunia yang selalu berubah. Kedelapan dimensi tersebut adalah:

- Managing global market;

- Building new kind of alliance between the public and private sector;

- Balancing competition with collaboration;

- Drawing investors into corporate environment;

- Accepting corporate responsibility;

- designing new form of organizations;

- Integrating sub cultures;

- Turning every employee into the new millennium.

Salah satu dari delapan dimensi tersebut adalah mendesain bentuk baru organisasi. Desain bentuk baru organisasi tersebut diarahkan kepada perubahan-perubahan beberapa karakteristik. Pertama, organisasi bergerak dari bentuk independen ke interdependen. Kedua, organisasi bergerak dari organisasi khierarkis ke organisasi networks. Ketiga, bergerak dari model partisipasi ke budaya kemitraan (Taket and White, 2000:13). Bentuk baru organisasi pada masa depan juga terkait dengan peristilahan kemitraan dalam pelayanan publik. Pada bidang publik, kemitraan mengacu pada situasi saling memberi dukungan antar organisasi dalam rangka pelayanan publik. (Taket and White, 2000:14). Hal ini dicirikan oleh karakteristik berikut:

- Sekurang-kurangnya ada dua lembaga yang berbeda, sektor publik dengan private atau sektor nonprofit.

- Adanya perjanjian tertulis untuk menentukan kerangka kemitraan.

- Adanya tujuan (pada umumnya penyelenggaraan pelayanan publik).

- Adanya pembagian tanggung jawab yang terdiri dari pembagian risiko, sumber daya, biaya, dan manfaat, baik yang bersifat tangible maupun intangible. 
Dari definisi ini, unsur-unsur kemitraan dapatlah disebutkan sebagai berikut: kesukarelaan, kerja sama, upaya ke arah pembangunan berkelanjutan, alokasi yang efisien atas sumber daya komplementer yang dicurahkan, serta keterlibatan sektor perusahaan, kelompok masyarakat sipil dan pemerintah. Kalau keseluruhan unsur tersebut muncul, maka potensi bagi penyelenggaraan program pembangunan yang unggul memang sudah memadai.

Tujuan dan manfaat dibentuknya kemitraan adalah untuk mencapai hasil yang lebih baik, dengan saling memberikan manfaat antar pihak yang bermitra, Hafsah (2000:5462) mengemukakan mengenai manfaat yang dapat diperoleh dalam kemitraan, beberapa diantaranya yaitu:

- Kemitraan dapat meningkatkan produktivitas organisasi;

- Kemitraan dapat membantu organisasi mencapai tujuan dengan lebih efisien;

- Kemitraan mengurangi beban risiko yang ditanggung oleh organisasi dengan membaginya;

- Kemitraan memberikan dampak sosial yang besar.

Ada beberapa persyaratan bagi keberhasilan kerja kemitraan yang melibatkan kepentingan semua pihak yang terlibat, yaitu badan-badan dan departemen pemerintah dan masyarakat setempat sendiri. Bryden, et al, (1998) mengajukan pedoman terselenggaranya proses ini, yang meliputi pelatihan semua pihak yang terlibat, penggunaan secara hatihati bahasa yang digunakan ketika berinteraksi dengan orang-orang setempat, penggunaan contoh-contoh dan penghubung, akuntabilitas dan kepemerintahan yang terbuka, menjabarkan tujuan-tujuan ke dalam tugas-tugas yang mudah dicapai, pesta keberhasilan, menjaga masyarakat setempat sadar informasi, dan adaptasi secara terusmenerus untuk menghadapi perubahanperubahan dan kebutuhan-kebutuhan baru.

Pada pihak lain, Agranoff dan Mc Guire $(2004,183)$ menambahkan perlunya kepemimpinan dan kemampuan memandu, sebab pengelolaan networks bukan sekedar konsensus atau suatu tindakan yang diambil bersama tetapi juga dukungan ide atas kon-sensus dari organisasi masing-masing.

Kemitraan Pemerintah-Swasta-Masyarakat (Public Private Community Partnership) merupakan suatu model kemitraan yang didasarkan pada kerangka penyedia terbaik (Best Sourcing). Dengan kerangka Best Sourcing tersebut pemerintah dapat mendorong sektor swasta-masyarakat untuk terlibat dalam memberikan pelayanan publik tertentu yang mana hal itu akan lebih meningkatkan efisiensi dan efektivitas pelayanan (value for money) dan memberikan win-win solution baik bagi pemerintah, pihak swasta maupun masyarakat.

\section{POLA KEMITRAAN PEMERINTAH, SWASTA DAN MASYARAKAT}

Jika mengacu pada teori barang publik, maka pada dasarnya pelayanan publik merupakan tanggungjawab pemerintah dalam menyediakannya, sedangkan untuk barang privat sektor swastalah yang menyediakan. Namun dalam kenyataannya terdapat beberapa barang campuran, yaitu barang semi publik (quasi public goods) dan semi privat (quasi private goods). Pelayanan publik meliputi penyediaan barang publik murni, semi publik, dan semi privat. Untuk kategori barang campuran ini, baik sektor publik maupun swasta dapat sama-sama menyediakan. Oleh karena itu untuk meningkatkan efisiensi dan efektivitas pelayanan publik, pemerintah daerah dapat melakukan program kemitraan dengan sektor swasta (public private partnership) atau bisa juga bekerjasama dengan sektor ketiga yaitu dengan organisasi nonprofit dan LSM (Mardiasmo, 2004). Selanjutnya Nurcholis (2005: 180) secara rinci membagi fungsi pelayanan publik ke dalam bidang-bidang sebagai berikut:

- Pendidikan.

- Kesehatan.

- Keagamaan.

- Lingkungan: tata kota, kebersihan, sampah, penerangan.

- Rekreasi: taman, teater, musium, turisme.

- Sosial.

- Perumahan. 
- Pemakaman/krematorium.

- Registrasi penduduk: kelahiran, kematian.

- Air minum.

- Legalitas (hukum), seperti KTP, paspor, sertifikat, dll.

Di dalam pelaksanaannya komposisi kemitraan yang disarankan kepada otoritas lokal terdiri dari (Chapman dalam Sumartono, 2008) :

- Lembaga-lembaga pemerintah

- Otoritas lokal

- Bisnis swasta dan organisasi-organisasi komersial

- Kelompok-kelompok masyarakat

- Organisasi-organisasi lingkungan

- Kelompok-kelompok sukarela, dan Individu-individu pribadi.

Bentuk kerjasama pemerintah dengan swasta/masyarakat bisa berupa kontrak kerja, tender penyediaan barang atau jasa, atau bisa juga berupa Business Process Outsourcing (OECD, 2001). Model kemitraan yang dapat diadopsi antara lain:

Gambar 1.

Hubungan Kemitraan Sektor Publik, Sektor Swasta dan Sektor Ketiga (Masyarakat)

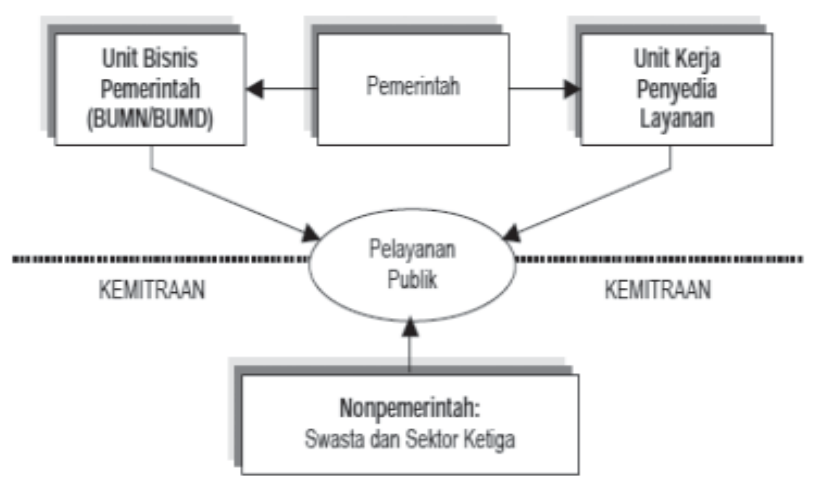

Sumber: Mahmudi, 2007:55

1. Operasi-Pemeliharaan

(Operation-Maintenance)

Pada Operation-Maintenance, sektor publik menyewa sebuah organisasi swasta untuk mengerjakan satu atau lebih tugas atau pelayanan publik selama lima sampai tujuh tahun. Sektor publik masih sebagai penyedia pelayanan yang utama sedangkan organisasi swasta mengerjakan pelayanan yang diserahkan kepada pihak luar oleh sektor publik. Sektor swasta harus menentukan pelayanan publik yang sesuai dengan biaya dan pelayanan tersebut harus sesuai dengan standar yang telah ditetapkan oleh sektor publik. Secara umum, pemerintah menggunakan prosedur kompetitif untuk memilih pihak yang menyelenggarakan service contract. Pembelian tersebut harus didasarkan pada waktu pelaksanaan yang lebih singkat dan yang membutuhkan sumberdaya yang sedikit (Bennet dalam Suhartono, 2005: 74).

2. Bangun-Transfer-Operasi (Build-Oper-ate-Transfer) Build-Operate-Transfer Contract (BOT) didesain untuk membawa investasi sektor swasta membangun infrastruktur baru. Pada BOT, sektor swasta akan membangun, membiayai, dan mengoperasikan infrastruktur baru dan system baru yang sesuai standar pemerintah. Periode operasi adalah cukup lama agar sektor swasta dapat menerima kembali biaya-biaya konstruksi dan mendapatkan keuntungan. Jangka waktu operasi tersebut adalah 1920 tahun. Setelah periode operasi selesai, seluruh infrastruktur diserahkan kepada pemerintah (Bastian, 2001). Pemerintah berkedudukan sebagai pemilik fasilitas infrastruktur, sekaligus menjadi konsumen dan regulator dari pelayanan tersebut (Bennet dalam Suhartono, 2005: 75).

\section{Wrap Around Addition}

Kemitraan bentuk Wrap Around Addition merupakan kerjasama antara pemerintah daerah dengan swasta yang dalam hal ini partner swasta mendanai dan membangun tambahan fasilitas publik yang tersedia. Partner swasta juga mengoperasikannya sampai tenggang waktu tertentu sampai dengan modal partner swasta kembali ditambah keuntungan yang diinginkannya. Kemitraan jenis ini dapat diaplikasikan pada hampir seluruh infrastruktur dan fasilitas publik termasuk jalan, air bersih, 
pengolahan limbah dan lain sebagainya (Mahmudi, 2007:57).

\section{Sewa-Beli (Leasing)}

Sewa-Beli merupakan jenis kemitraan yang dalam hal ini pemerintah daerah melakukan kontrak kepada partner swasta untuk melakukan desain, pembiayaan, dan membangun fasilitas untuk layanan publik. Partner swasta kemudian menyewakan kepada Pemda sampai dengan kepemilikan fasilitas menjadi milik pemerintah. Hal ini dilakuan ketika Pemda ingin menyediakan fasilitas layanan akan tetapi tidak bersedia memberikan pendanaan. Sewa-Beli dapat digunakan untuk pembangunan modal seperti gedung, armada kendaraan, air bersih dan penyediaan fasilitas komputer (Mahmudi, 2007:58).

\section{Pelayanan Berbasis Masyarakat} (Community-Based Provision) Community-based provision berawal ketika keterbatasan keuangan menghadang pemerintah untuk memberikan pelayanan yang cukup untuk masyarakat. Сотmunity-based provision mendorong anggota masyarakat untuk memenuhi kebutuhannya sendiri. Anggota dari Community based provision meliputi individual, keluarga atau perusahaan dalam ruang lingkup mikro. Seringkali beberapa aktivitas tidak dapat diakui dan tidak dapat terintegrasi dalam system yang formal. Di beberapa kota dimana pemerintah mengakui adanya $N G O, N G O$ akan memberikan bantuan pada group non-formal ini secara terorganisir. $N G O$ menyediakan input untuk proses manajemen media negosiasi antara CBO dengan lembaga politik yang lebih luas, jaringan kerja, dan penyebaran informasi (Bennet dalam Suhartono, 2005:78)

Bila model kemitraan ini diterapkan, setidaknya terdapat tujuh kemungkinan pola interaksi kemitraan; pertama, seratus persen pengaturan, kontrol dan evaluasi dilakukan pemerintah secara otonom dan mandiri.
Kedua, ada interaksi antara sektor publik dan sektor swasta. Interaksi ini terjadi pada derajat yang berbeda, bisa 99\% publik dan 1\% swasta atau sebaliknya 1\% publik dan 99\% swasta. Ada elemen-elemen yang contracting out (misalnya perawatan kendaraan, kebersihan) atau pembagian tugas (tindakan preventif dan pembangunan saluran hidran).

Ketiga, dimungkinkan 100\% peran sektor swasta, dengan tidak melibatkan masyarakat dan pemerintah, artinya penyediaan pelayanan sepenuhnya dikelola swasta, dengan tidak ada keterlibatan pemerintah baik pada regulasi maupun penyediaan fasilitas.

Keempat, ada interaksi antara pemerintah dan masyarakat. Pegawai fasilitas pelayanan, misalnya, merupakan kombinasi antara tenaga profesional pemerintah dan sukarelawan masyarakat.

Kelima, urusan pelayanan publik 100\% menjadi urusan masyarakat. Tidak ada organisasi pemerintah maupun swasta yang telibat dalam perencanaan, pengadaan, dan penanganan masalah tersebut.

Keenam, kombinasi antara organisasi swasta yang berorientasi pada profit dengan LSM yang non profit. Lembaga penyedia pelayanan mungkin ditangani swasta, tetapi dikombinasikan dengan tenaga profesional dan warga masyarakat. Yang terakhir merupakan kombinasi dari tiga pilar governance: pemerintah (publik), swasta, dan masyarakat. Kombinasi tersebut sama dengan interaksi antara pemerintah-swasta (public-private) tetapi dengan tambahan tenaga sukarelawan dari masyarakat (Paskarina, 2007:8).

Setiap bentuk kemitraan, masing-masing mengandung potensi keuntungan dan kerugian. Oleh karena itu, perencanaan yang baik, manajemen risiko, dan penilaian mendalam tentang skema kemitraan mutlak harus dilakukan agar pemerintah tidak dirugikan yang pada akhirnya masyarakatlah yang dirugikan.

\section{KEMITRAAN SEBAGAI PERWUJUDAN GOOD GOVERNANCE DALAM PELAYANAN PUBLIK}

Harus diakui bahwa penerapan sistem 
kemitraan di Indonesia masih merupakan hal yang baru dan belum banyak dipahami dengan baik oleh para perumus kebijakan di daerah. Akan tetapi dari beberapa kasus di daerah yang telah berhasil menerapkannya, tampak bahwa sistem kemitraan bisa merupakan terobosan bagi penciptaan mekanisme pelayanan yang lebih berkualitas serta reformasi birokrasi publik di Indonesia. Kemitraan dalam pelayanan publik jelas sangat sesuai dengan gagasan tata pemerintahan yang baik sebab prinsip dasar dari governance adalah keterlibatan tiga pihak dalam proses pelayanan, yaitu pemerintah daerah, unsur-unsur swasta, dan unsur-unsur masyarakat sebagai pengguna jasa pelayanan.

Secara teoritis yang dikemukakan Tascereu dan Campos (Thoha, 2003:63), tata pemerintahan yang baik ( terjemahan good governance) merupakan suatu kondisi yang menjamin adanya proses kesejajaran, kesamaan, kohesi dan keseimbangan peran serta, adanya saling mengontrol yang dilakukan oleh komponen yaitu pemerintahan (government), rakyat (citizen) atau civil society dan usahawan (business) yang berada di sektor swasta. Ketiga komponen itu mempunyai tata hubungan yang sama dan sederajat.

Jika kesamaan derajat itu tidak sebanding atau tidak terbukti maka akan terjadi pembiasan dari tata pemerintahan yang baik. Oleh karena itu, dalam konteks good governance, pemerintah ditempatkan sebagai fasilitator atau katalisator, sementara tugas untuk memajukan dan mengawal proses pelaksanaan pembangunan terletak pada semua komponen negara, meliputi kelompok-kelompok private (dunia usaha) dan civil society yang meliputi kelompok-kelompok infrastruktur politik (Lembaga Swadaya Masyarakat-LSM, kelompok penekan, partai politik, Perguruan Tinggi dan organisasi kemasyarakatan lainnya. Atas dasar tersebut, untuk mewujudkan tata pemerintahan yang baik sesungguhnya adalah bagaimana membangun kemitraan dan komunikasi yang baik antara ketiga aktor tersebut.

Istilah governance sebenarnya sudah dikenal dalam literatur administrasi dan ilmu politik hampir 120 tahun, sejak Woodrow
Wilson memperkenalkan bidang studi tersebut kira-kira 125 tahun yang lalu. Tetapi selama itu governance hanya digunakan dalam konteks pengelolaan organisasi korporat dan lembaga pendidikan tinggi. Wacana tentang governance yang baru muncul sekitar beberapa tahun belakangan ini, terutama setelah berbagai lembaga pembiayaan internasional mempersyaratkan good governance dalam berbagai program bantuannya. Oleh para teoritisi dan praktisi administrasi negara Indonesia, term good governance diterjemahkan menjadi penyelenggaraan pemerintahan yang amanah, tata kepemerintahan yang baik, pengelolaan pemerintahan yang baik dan bertanggunjawab, ada juga yang mengartikan secara sempit sebagai pemerintahan yang bersih (Sofyan Efendi, 2005:2).

Perbedaan paling pokok antara konsep government dan governance terletak pada bagaimana cara penyelenggaraan otoritas politik, ekonomi dan administrasi dalam pengelolaan urusan suatu bangsa. Konsep government berkonotasi bahwa peranan pemerintah yang lebih dominan dalam penyelenggaran berbagai otoritas negara. Sedangkan dalam governance mengandung makna bagaimana cara suatu bangsa mendistribusikan kekuasaan dan mengelola sumberdaya dan berbagai masalah yang dihadapi masyarakat. Dengan kata lain, dalam konsep governance terkandung unsur demokratis, adil, transparan, rule of law, partisipatif dan kemitraan (Sofyan Efendi, 2005:2).

Kemudian secara implisit kata good dalam good governance sendiri mengandung dua pengertian; pertama, nilai yang menunjung tinggi kehendak rakyat dan nilai yang meningkatkan kemampuan rakyat dalam mencapai tujuan kemandirian dan keadilan sosial. Kedua, aspek fungsional dari pemerintahan yang efektif dan efisien dalam pelaksanaan tugasnya untuk mencapai tujuan tersebut (Tjahjanulin Domai, 2005:6).

Prinsip-prinsip yang melandasi konsep tata pemerintahan yang baik sangat bervariasi dari satu institusi ke institusi lain, dari satu pakar ke pakar lainnya. Namun paling tidak ada sejumlah prinsip yang dianggap sebagai landasan good governance, yaitu akuntabilitas, 
transparansi, dan partisipasi masyarakat. Selain itu juga, Good Governance yang efektif menuntut adanya koordinasi dan integritas, profesionalisme serta etos kerja dan moral yang tinggi dari ketiga pilar yaitu pemerintah, masyarakat madani, dan pihak swasta.

Governance mengasumsikan banyak aktor yang terlibat dimana tidak ada yang sangat dominan yang menentukan gerak aktor lain. Pesan pertama dari terminologi governance membantah pemahaman formal tentang bekerjanya institusi-institusi negara. Governance mengakui dalam masyarakat terdapat banyak pusat pengambilan keputusan yang bekerja pada tingkat yang berbeda. Menurut UNDP, governance atau tata pemerintahan memiliki tiga domain yaitu (Sedarmayanti, 2009:270):

a. Negara atau tata pemerintahan (state);

b. Sektor swasta atau dunia usaha dan (private sector;)

c. Masyarakat (society).

Ketiga domain dalam Governance tersebut berada dalam kehidupan berbangsa, bernegara dan bermasyarakat. Sektor pemerintahan lebih banyak memainkan peranan sebagai pembuat kebijakan, pengendalian dan pengawasan. Sektor swasta lebih banyak berkecipung dan menjadi penggerak aktifitas di bidang ekonomi. Sedangkan sektor masyarakat merupakan objek sekaligus subjek dari sektor pemerintahan maupun swasta. Karena di dalam masyarakatlah terjadi interaksi di bidang politik, ekonomi, maupun sosial budaya (Wasistiono, 2009:31).

Membangun, mewujudkan/menerapkan good governance, bukan hanya berupa masalah perbaikan kondisi dan komitmen birokrasi dan administrasi publik saja, tetapi juga perbaikan kondisi dan komitmen dunia usaha dan masyarakat yang memiliki berbagai macam kelompok sosial dengan kondisi dan kepentingan yang berbeda. Ketiga unsur tersebut, yaitu pemerintah, dunia usaha dan masyarakat harus secara bersama-sama/ mengadakan hubungan kemitraan berupaya mewuudkan terlaksananya good governance (tata pemerintahan yang baik).

Penyediaan pelayanan sosial dasar yang bermutu oleh lembaga-lembaga yang kompe- ten, bertanggung jawab dan akuntabel, sering dipandang sebagai perwujudan dari tata pemerintahan yang baik. Dalam tata pemerintahan, mutu pelayanan mencerminkan titik temu antara permintaan dan penawaran serta menjadi faktor penentu peningkatan standar dan kualitas hidup.

Konsep kemitraan menjadi penting untuk didiskusikan, karena adanya kesadaran bahwa persoalan-persoalan pembangunan tidak dapat lagi dilihat hanya dari kepentingan dan tanggung jawab satu kelompok saja. Pembangunan telah menjadi kesadaran baru sebagai 'kerja patungan' dan bukan sebagai 'single fighter' dari pemerintah saja.

Pemerintah tidak mungkin lagi mengerjakan semua urusan karena keterbatasan dana dan sumber daya manusia, sehingga kerjasama dan kemitraan dengan pihak-pihak lain harus dilakukan agar kualitas pelayanan publik tetap dapat dipenuhi sesuai dengan tuntutan masyarakat. Keterbatasan sumber daya yang dimiliki oleh pemerintah dalam pelaksanaan pembangunan dan pelayanan publik sementara tuntutan masyarakat terhadap kualitas pelayanan publik semakin meningkat. Sebagai suatu konsep, kemitraan pemerintah-dunia usaha-masyarakat diprediksi dapat meningkatkan kualitas pelayanan publik.

\section{E. KESIMPULAN}

Kemitraan pemerintah, swasta, dan masyarakat perlu dikembangkan agar penyediaan pelayanan publik menjadi lebih dekat dan mudah diakses masyarakat. Berbagai model jejaring kemitraan perlu dikembangkan tidak hanya untuk mengantisipasi tuntutan pelayanan publik, tapi juga untuk mengantisipasi dominasi pemerintah atau pasar dalam penyediaan barang dan jasa publik.

Dominasi pemerintah akan menciptakan ketergantungan dan meminimalkan inovasi serta posisi tawar masyarakat terhadap kualitas pelayanan yang diberikan. Sebaliknya, dominasi pasar dalam penyediaan public goods akan menyebabkan monopoli yang eksploitatif dan meminimalkan akses masyarakat terhadap pelayanan publik yang berkualitas. 
Karena itu, model jejaring kemitraan menjadi alternatif untuk mengatasi kelemahankelemahan tersebut agar pelayanan publik yang berkualitas menjadi lebih mudah diakses masyarakat.

Di kota-kota seluruh dunia, pemerintah telah menemukan bahwa keterlibatan tiga domain adminstrasi publik (pemerintahswasta-masyarakat) dapat meningkatkan kualitas pelayanan publik, melalui penurunan biaya dan perluasan cakupannya. Dengan pelayanan publik demikian dapat meningkatkan kualitas kehidupan masyarakat.

\section{DAFTAR PUSTAKA}

Agranoff, Robert., and Michael Mc Guire. 2004. Collaborative Public Management: New Strategies for Local Government. Washington: Georgetown University Press

Borrini-Feyerabend, G. 1996. Collaboration Management of Protected Area: Tailoring the Approach to the Context. Social Policy Group IUCN. http:// www.iucn.org/ (download 12-1-2011)

Bryden, J.S.M., and Murphy, C. 1998. Evaluation and Monitoring of the Loggan Community Forestry I nitiative, Inception Report and Final Refort. Scottish Office, Edinburh. www.abdn.ac.uk/arkleton/ npp/parte

Eisler, R \& Montuori, A. 2001. The Partnership Organization: A System Approach. O.D. Practitioner, Vol. 33, No. 2. http:// www.bepress.com?article (download 10-2-2011)

Hanif, Nurcholis. 2005. Teori dan Praktek Pemerintahan dan Otonomi Daerah. Jakarta: Trasindo.

Hodgett, S., and Johnson, D. 2001. Troubles, Partnerships and Possibilities: A Study of the Making Belfast Work Development Initiative in Nerthern Ireland. Journal Public Administration \& Devel- opment: Oct 2001; 21, 4; ABI/INFORM Research. Pg 321-332

Larasati, Endang. 2008. Reformasi Pelayanan Publik (Public Services Reform) dan Partisipasi Publik. "Dialogue" JIAKP, Vol. 5, No. 2, Mei 2008 : 254-267

Mahmudi. 2007. Kemitraan Pemerintah Daerah dan Efektivitas Pelayanan Publik. Jurnal Sinergi Kajian Bisnis dan Manajemen Vol. 9 No. 1, Januari 2007 hal. $53-67$

Mardiasmo. 2004. Otonomi \& Manajemen Keuangan Daerah. Yogyakarta: Penerbit ANDI.

Paskarina, Carolina. 2007. Kemitraan Pemerintah-Swasta dalam Pelayanan Publik. Warta Bapeda: www.bapedajabar.go.id

Sedarmayanti. 2009. Reformasi Administrasi Publik, Reformasi Birokrasi, dan Kepemimpinan Masa Depan (Mewujud-kan Pelayanan Prima dan Kepemerin-tahan yang Baik. Bandung: Refika Aditama

Sofyan Efendi. 2005. Membangun Budaya Birokrasi untuk Good Governance. Lokakarya Reformasi Birokrasi. Jakarta: Departemen Pemberdayaan Aparatur Negara.

Suhartono. Ehrmann. 2005. Model-model Public Private Partnership pada Sektor Pelayanan Air Bersih. Jurnal Akuntansi dan Bisnis. Volume 5 No. 1 Pebruari 2005: 72-81

Sumartono. 2008. Kemitraan Pemerintah Desa dengan Badan Perwakilan Desa dalam Penyelenggaraan Pemerintahan Desa. Disertasi (Tidak Diterbitkan), UGM.

Taket \& White. 2000. Partnership and Participation, Decision Making in the Multiagency Setting. http://www. tower.com/partnership-participation- 
decision-making-in-multiagency-setting-a-r-taket

Tjahjanulin Domai. 2005. Dari Pemerintahan ke Pemerintahan yang Baik. Jakarta: Depdagri.

Thoha, Miftah. 2003. Birokrasi Politik di Indonesia. Jakarta: Raja Gravindo Persada
Vigoda, Eran., 2002, From Responsiveness to Collaboration: Governance, Citizens, and the Next Generation of Public Administration, dalam Public Admi-nistration Review, Vol. 62, No. 5, Hal. 527-540.

Wasistiono, Sadu. 2009. Kapita Selekta Penyelenggaraan Pemerintahan Daerah. Bandung: Fokus Media. 